\title{
Transcription factors in mouse fetal thymus development
}

\author{
Vladimir Ivanov ${ }^{1,2}$ and Rhodri Ceredig' \\ IINSERM Unite 184, Laboratoire de Génétique Moléculaire des Eucaryotes du CNRS, Institut de Chimie \\ Biologique, Faculté de Médecine, 11 rue Humann, 67085 Strasbourg Cedex, France \\ ${ }^{2}$ Institute of Gene Biology, Russian Academy of Sciences, Moscow B334, Russia
}

Key words. NF-xB CREB, NF-IL-2A, NF-AT1, band-shitt assay

\begin{abstract}
T cell precursors from murine fetal liver enter the fetal thymus where they proliferate, differentiate, and mature. These processes are accompanied by changes in the pattern of transcription factors known to control the expression of specific genes. We have monltored the expression of five different transcription factors during mouse fetal thymus ontogeny: nuclear factor (NF)- $x$ B, cAMP-response-element binding protein (CREB), NF-IL-2A, msNF-AT1, and hNFAT1. NF- $x$ B binding activity was not detected in extracts from fetal liver but was present in the thymus at day 14 of embryogenesis. Thereafter, NF- $x B$ expression was biphasic, being maximal at 14 - 16 days gestation and in newborn mice, and decreased during the intermedlate gestational stages and in the adult. An inverse correlation was observed between NF- $x$ B binding activity in the nuclel and levels of its inactive precursor in the cytoplasm of all samples analyzed. In contrast, CREB activity was uniform throughout thymus development. Similarly, NF-IL-2A activity was detected In fetal liver and thymic extracts from different gestatlonal stages, In approximately equivalent amounts. However, band shift experiments revealed three distinct NF-IL-2A - DNA complexes, whose relative abundance is altered during thymic ontogeny. Likewise, NF-AT1 transcription factor appears to be heterogeneous and includes representatives which are differentially (msNF-AT1) or stably (hNF-AT1) expressed during thymic development. These results are discussed in the context of present knowledge about $T$ cell development withln the thymus.
\end{abstract}

\section{Introduction}

Complex cell - cell interactions, hormones, growth factors, and other extracellular inducers are known to activate specific patterns of genes in target cells during development or in response to the environment. Regulation of gene expresston occurs at several different levels, but the activation of trans-actıng protein factors of transcription (which mediate differential gene transcription by binding to their cognate cis-acting elements in gene promoters and enhancers) is perhaps the most fundamental $(1,2)$. Regulatory regions of eukaryotic genes contain specific combinatorial patterns of cis-acting elements, which are frequently similar and bind ubiquitous transcription factors. However, some transcription factors have a more restricted tissue or cell distribution and mediate tissuespecific gene expression. The best examples of such are the transactivator MyoD, a product of the muster regulatory gene for myogenesis $m y o D$, the transcription factor GATA-1, which is restricted to hematopoietıc cells, and the transcription factor HNF 1/LFB1 that is enriched in the liver $(3-5)$ Until now, relatively little information has been avarlable regarding $T$ cell specific or $T$ cell associated transcription factors. Possible candidates include TCF $1 \alpha / L E F 1$, which is essential for T cell receptor $\alpha$ chain (TCR- $\alpha$ ) and CD4 gene transcription $(6,7)$, and GATA-3, which binds to several TCR regulatory elements $(8,9)$. Much more is known about ubiquitous transcription factors such as nuclear factor (NF)- $x \mathrm{~B}$ and cAMP-responsive-element binding protein (CREB). NF- $x$ B activity has been found in nuclear fractions of many different cell types, but particularly within nuclei of cells of the immune system. Most target genes for this factor can be divided into three groups: (i) genes encoding immunomodulatory cytokines such as IL-2, IL-6, tumor necrosis factor- $\alpha$ (TNF- $\alpha$ ), and granulocyte macrophage colony stimulating factor (GM-CSF), (ii) genes encoding immunoregulatory surface receptors such as IL-2 receptor $\alpha$ chain $(\mathrm{IL}-2 \mathrm{R} \alpha)$, the $\mathrm{MHC}$ class 
I proteins (MHC I) and the invariant chain of MHC class II; and (iii) acute phase proteins including serum amylord $A$ precursor (for reviews, see refs 10 and 11).

CREB is responsible for transcriptional activation of different CAMP-inducible genes (for review, see ref. 12). CREB, or related proteins, activate the murine TCR- $\beta$ chain transcription, binding to the cis-element CRE found in the $V_{\beta}$ promoter and TCR- $\beta$ enhancer regions $(13,14)$. In addition, the transactivator CREB is known to bind to both human and mouse $3^{\prime}$ TCR- $\alpha$ enhancers (15) and a CRE motif has been found in the $3^{\prime}$ enhancer of the human CD2 gene (16).

There are at least two other important regulators of transcription in T lymphocytes, i.e. factors NF-AT1 and NF-IL2A. These factors recognize cognate elements which were originally described within the $\mathrm{IL}-2$ gene regulatory region $(17-20)$. Recently, it has been shown that the NF-AT1 binding site has a complex structure and also contains an Ets cognate sequence (21). In addition, Ets binding sites have been found in the regulatory regıons of many genes having T cell specific expression, i.e. CD2, CD3 CD3 $\epsilon$, TCR- $\alpha$, TCR- $\beta$, and TCR- $\delta(21)$.

Most studies dealing with transcription factors and the genetic regulatory events in T lymphocytes have been restricted to examining events in mature T cell activation (22). Relatively little is known about transcriptional control in developing thymocytes. However, because complex cell-cell interactions between stroma and thymocytes are known to control development within the thymus, it seems likely that transcription factors mediate at least some of these events. T cell precursors derived from fetal Iiver enter the fetal thymus anlage via the blood stream and then undergo a complex series of differentiation and maturation events. During this process, rapidly dividing immature CD4-CD8- cells differentiate through an intermediate stage $\left(\mathrm{CD} 4^{+} \mathrm{CD} 8^{+}\right)$expressing both CD4 and CD8 before finally giving rise to cells expressing either $\mathrm{CD}^{+}$or $\mathrm{CD}^{+}$. These latter 'mature' thymocytes express clonally elaborated TCR molecules and are immunologically competent (for review, see ref. 23). During mouse fetal thymus development, $\mathrm{CD} 4+\mathrm{CD} 8^{+}$ (double positive) and cells expressing either CD4 or CD8 (single positive) appear at days 16 and $18-19$ respectively (24). In this study, we investigated the changes in transcription factor expression that accompany these complex intrathymic events. In the first instance, we examined nuclear and cytoplasmic extracts prepared from fetal thymocytes starting at day 14 of embryonic development for a variety of transcription factors. The results obtained showed that transcription factor levels are tightly regulated during thymic development.

\section{Methods}

\section{Oligonucleotides}

Synthetic oligonucleotides were end-labeled with [ $\gamma^{32}$ P]ATP using T4 polynucleotide kinase (25). Sequences of doublestranded oligonucleotides used in this study are shown in Table 1.

\section{Thymocyte preparation}

Cell suspensions were prepared from the thymuses of fetal, newborn, or 4 week old adult (C57BI/ $6 \times \mathrm{DBA} / 2) F_{\text {, mice. Fetal }}$ mice were obtained from timed matings of DBA/2 female and
C57BI/6 male mice, and the date of findıng the vaginal plug was taken as day 0 ol development. Fetal thymuses were removed using a dissecting microscope and cell suspensions prepared by passing thymus lobes through hypodermic needles of decreasing size as previousty described (26).

Nuclear and cytosol extract preparation and electrophoretıc mobility-shit assay (EMSA)

Nuclear and cytoplasmic extracts were prepared from fresh thymuses using a modification of the techique described by Dignam et al. $(27,28)$. Buffers contained the protease inhibitors phenyimethylsulfonyl fluoride (PMSF) $(0.5 \mathrm{mM})$, and $5 \mu \mathrm{g} / \mathrm{ml}$ each of leupeptın, aprotinin, pepstatin, chymostatin, and antıpain Protelns were quantified by the method of Bradford (29). Binding reactions were carried out by incubating the end-labeled DNA (20 000 c.p.m.) with $1-2 \mu \mathrm{g}$ of nuclear or $5-10 \mu \mathrm{g}$ cytoplasmic proteins and $2 \mu \mathrm{g}$ of poly $(\mathrm{dl}-\mathrm{dC})$ in a buffer containing $10 \mathrm{mM}$ HEPES ( $N$-2-hydroxyethylpiperazine- $N$ '-2-ethanesulfonic acid), $\mathrm{pH} 7.9,60 \mathrm{mM} \mathrm{KCl}, 4 \%$ Ficoll, $1 \mathrm{mM}$ EDTA (30). After $30 \mathrm{~min}$ at room temperature, the reaction mixtures were loaded onto a $4 \%$ polyacrylamide gel in $0.25 \times$ TBE buffer (TBE: $89 \mathrm{mM}$ Tris, $89 \mathrm{mM}$ boric acid, $2 \mathrm{mM}$ EDTA) and electrophoresed at $10 \mathrm{~V} / \mathrm{cm}$ for $1.5 \mathrm{~h}$ at room temperature. For competition experıments, a 100- to 400 -fold molar excess of unlabeled oligonucleotide was added to the reaction mixture prior to the addition of labeled DNA. The treatment of cytosolic fractions with $0.6 \%$ deoxycholate (DOC) in the presence of $1.2 \%$ NP-40 was performed during the bınding reaction as described by Baeuerle and Baltımore (31).

Photo-affinity labeling of sequence-specific proteins (UV crosslinking)

DNA-protein UV crosslinking was performed using a modification of the method reported by Wu et al. (32). The first stage of the binding reaction was the same as that for EMSA except for an increased concentration (up to $60000 \mathrm{c} \mathrm{p.m.)} \mathrm{of}$ the labeled DNA probes. After $30 \mathrm{~min}$ at room temperature, the reaction mixtures (in open tubes) were placed on ice $5 \mathrm{~cm}$ from an Inverted $254 \mathrm{~nm}$ UV transilluminator and irradiated for $20 \mathrm{~min}$. Then, an equal volume of $2 \%$ sodium dodecylsulfate (SDS), $10 \%$ 2-mercaptoethanol, $0.1 \mathrm{M}$ Tris $-\mathrm{HCl}, \mathrm{pH} 7.0,20 \%$ glycerol, and Bromphenol blue dye was added. The samples were boiled for 2 min and subjected to electrophoresis in $0.1 \%$ SDS - 10\% polyacrylamıde gels followed by autoradiography.

\section{Results}

$N F \cdot x B$ binding activity in fetal and adult thymus

To probe for NF-xB binding activity in nuclear extracts of thymocytes, EMSA was used with three different labeled probes: a $x \mathrm{~B}$ oligonucleotide from the human immunodeficiency virus (HIV) type 1 enhancer $(x \mathrm{~B})$, a mutated variant of this oligonucleotide with three point mutations in the binding site $\left(m_{x} B\right)$, and a palindromic variant of the $x B$ element from the $M H C$ class I gene promoter region (MHC-xB) (Table 1). Incubation of the radiolabeled $x \mathrm{~B}$ oligonucleotide with nuclear extracts of thymocytes from newborn and adult mice revealed two discrete, electrophoretically retarded DNA - protein complexes (b1 and b2) (Fig. 1). These two bands were observed more clearly after 
Table 1. Oligonucleotide with binding sites for transcription factors

\begin{tabular}{|c|c|c|}
\hline $\begin{array}{l}\text { Oligonucleotides }{ }^{\mathrm{a}} \\
\left(5^{\prime}-3\right)\end{array}$ & $\begin{array}{l}\text { Binding stes and } \\
\text { transcription } \\
\text { factors }\end{array}$ & $\begin{array}{l}\text { Gene } \\
\text { promoters } \\
\text { or enhancers }\end{array}$ \\
\hline AGCTTGGGGACTITCCAGCCG & $x B / N F \cdot x B$ & HIV \\
\hline $\begin{array}{l}\text { AGCTT } \overline{\text { GGGGATTCCCC }} \text { ATCTG } \\
\text { AGCTTGCTCACTTCCAGCCG }\end{array}$ & $\begin{array}{l}\mathrm{MHC} \cdot x \mathrm{~B} / \mathrm{NF} \cdot x \mathrm{~B} \\
\mathrm{~m}_{x} \mathrm{~B}^{\mathrm{b}}\end{array}$ & $\mathrm{MHC} I\left(\mathrm{H} \cdot 2 \mathrm{~K}^{\mathrm{b}}\right)$ \\
\hline AGCIIITGGAATCTATCCAAGTCG & NF $1-/ N F 1$ & MMTV-LTR \\
\hline AGCTTGATGAGTCAGCCG & AP1-/AP1 & human collagenase \\
\hline AGCTCCATGACGTCATGG & CRE/CREB & TCR- $\alpha$ \\
\hline GGAGGAAAAACTGTTTCATACAGAAGGCGT & AT1 $\mathrm{C} / \mathrm{hNF}-\mathrm{AT} 1$ & human IL-2 \\
\hline GGAGTAAAAAATTTITAATACAGAAGGCGT & mAT1 ${ }^{b}$ & \\
\hline -GAGGAAAATTTGTTTCATACAGAAG & $\mathrm{msAT} 1 \mathrm{~b} / \mathrm{msNF} \cdot \mathrm{AT}$ & murine IL-2 \\
\hline GAAAATATGTGTAATATGTAAAACATTTTG & IL-2A $/$ /NF-IL2A & human IL-2 \\
\hline AGCTTGATTTGCATTTCTG & Oct/OTF & Ig $x$ chain \\
\hline
\end{tabular}

${ }^{a}$ Known binding sites of transcription factors are underlined.

${ }^{b}$ Mutated nucleotides are shown in bold.

cEts-bynding site is shown in italic

dNon-canonical Oct-binding site is shown in ralic.

shorter exposure of autoradiograms ( $F i g .2$, panel B). The formation of these complexes was inhibited by preincubation with a 200 -fold molar excess of unlabeled $x$ B olıgonucleotide but was not inhıbıted by excess unlabeled $\mathrm{m}_{x}$ B olıgonucleotıde (Fıg. 1, lanes 2,5 and 3,6 respectively). Incubation of the radiolabeled $\mathrm{m}_{*} \mathrm{~B}$ oligonucleotide with nuclear extracts from newborn or adult thymocytes did not produce any significant DNA-protenn complexes (Fig. 1, lanes 7 and 8 ). Hence, NF- $x$ B binding activity was specific in nuclear extracts from mouse thymocytes.

Using labeled MHC- $x$ B oligonucleotides, EMSA produced the same retarded DNA - protein complexes as with the $x \mathrm{~B}$ probe (Fig. 1, lane 9, bands b1 and b2). However, two differences were noted between EMSA experiments with the $x \mathrm{~B}$ and $\mathrm{MHC} \cdot x \mathrm{~B}$ oligonucleotides. Firstly, a shorter exposure of EMSA showed that with the MHC- $x \mathrm{~B}$ oligonucleotide (Fig. $2 \mathrm{C}$, lanes $10-12$ ), the two bands b1 and b2 were of approximately equal intensity for newborn thymus extracts, whereas with the $x \mathrm{~B}$ oligonucleotide ( $F$ ig. 2B) band b1 was consistently more intense than band b2. Secondly, in competition experiments, a 200-fold excess of unlabeled $x^{8}$ B-oligonucleotide failed to completely inhibıt the appearance of band b2 (Fig. 1, lane 11). Taken logether, these results would seem to agree with the recent reports of Ghosh et al. (33) and Urban and Baeuerle (34) who suggested that the upper band b1 may result from the interaction of the heterodimeric p65-p50 form of NF- $x$ B with the $x B$ oligonucleotide, while the lower band $b 2$ was the result of the interaction of the homodimeric $\mathrm{p} 50-\mathrm{p} 50$ form of $\mathrm{NF} \cdot x \mathrm{~B}$ with the same probe. These results suggest that the palindromic MHC$x \mathrm{~B}$ oligonucleotide may bind equally well to both isoforms of $\mathrm{NF}-x \mathrm{~B}$, whereas the non-palindromic $x \mathrm{~B}$ oligonucleotide has a higher affinity for the $065-p 50$ NF- $x B$ complex.

We used UV crosstinking of the $x \mathrm{~B}$ probe to $\mathrm{NF}-x \mathrm{~B}$-like proteins from newborn thymocyte extracts to determine the subunit composition of these proteins (Fig. 1B). Taking into account the molecular weight of the oligonucleotide probe, SDS-PAGE showed that newborn thymus NF-xB-like protein had the canonical subunit composition for NF- $x$ B factor (35) with apparent molecular weights of 65 and $50 \mathrm{kDa}$. Labeling of these proteins was inhibited by a excess of $x$ B oligonucleotide but not of $\mathrm{m} x \mathrm{~B}$ oligonucleotide (Fig. 1B), again showing the specificity of the interaction being measured.

These experiments established the specificity of NF-xB detection. NF- $x$ B binding activity during mouse thymus ontogeny was then determined. Results of these experiments are shown in Fig. 2. The first time point studied was day 14 of embryonic development. For these experiments, nuclear extracts of thymocytes were prepared from a pool of 40-50 mice, equivalent to $1.5-2 \times 10^{6}$ cells, and in all experiments equal amounts of protein were used in each reaction. These studies showed that NF- $x$ B binding activity was high on days $14-16$ of development with a significant decrease durıng days 17 and 18. After birth, NF- $x \mathrm{~B}$ levels increased slightly before reaching the adult thymus level (Fig. 2). Importantly, the intensity of the upper b1 band, which corresponds to the p65-p50 complex of NF-xB , was greater early in fetal thymus development (Fig. $2 B$ and $C$, lane $1-3$ ). In the newborn thymus (lanes $10-12$ ) the intensity of bands b1 and b2 were approximately equal.

It is well known that in many different tissues there is a cytoplasmic precursor pool of NF- $x$ B factor. The heterodimeric complex of $p 65-p 50$ NF- $x$ B interacts with the inhibitory protein I $x \mathrm{~B}$ which keeps NF-xB in the cytoplasm in an inactive form $(36,37)$. Treating cytopłasmic extracts with DOC dissociates NF. $x \mathrm{~B}$ from $\mathrm{I} x \mathrm{~B}$ and thereby reveals the presence of an inactive cytoplasmic pool of NF-xB. Mouse fetal thymocyte cytoplasmic extracts were therefore exposed to DOC to measure their cytoplasmic NF- $x B$ content. Our results showed that between days 14 and 18 of development there was a significant increase in the cytoplasmic pool of NF-xB binding activity (Fig. 3, cf. lanes 3,7 and 11). This binding activity was competed by excess unlabeled $x \mathrm{~B}$ oligonucleotide (Fig. 3, lanes 8 and 12). Hence, during fetal thymus development, an inverse correlation between the levels of the nuclear NF-xB and of the cytoplasmic NF- $x B$ 


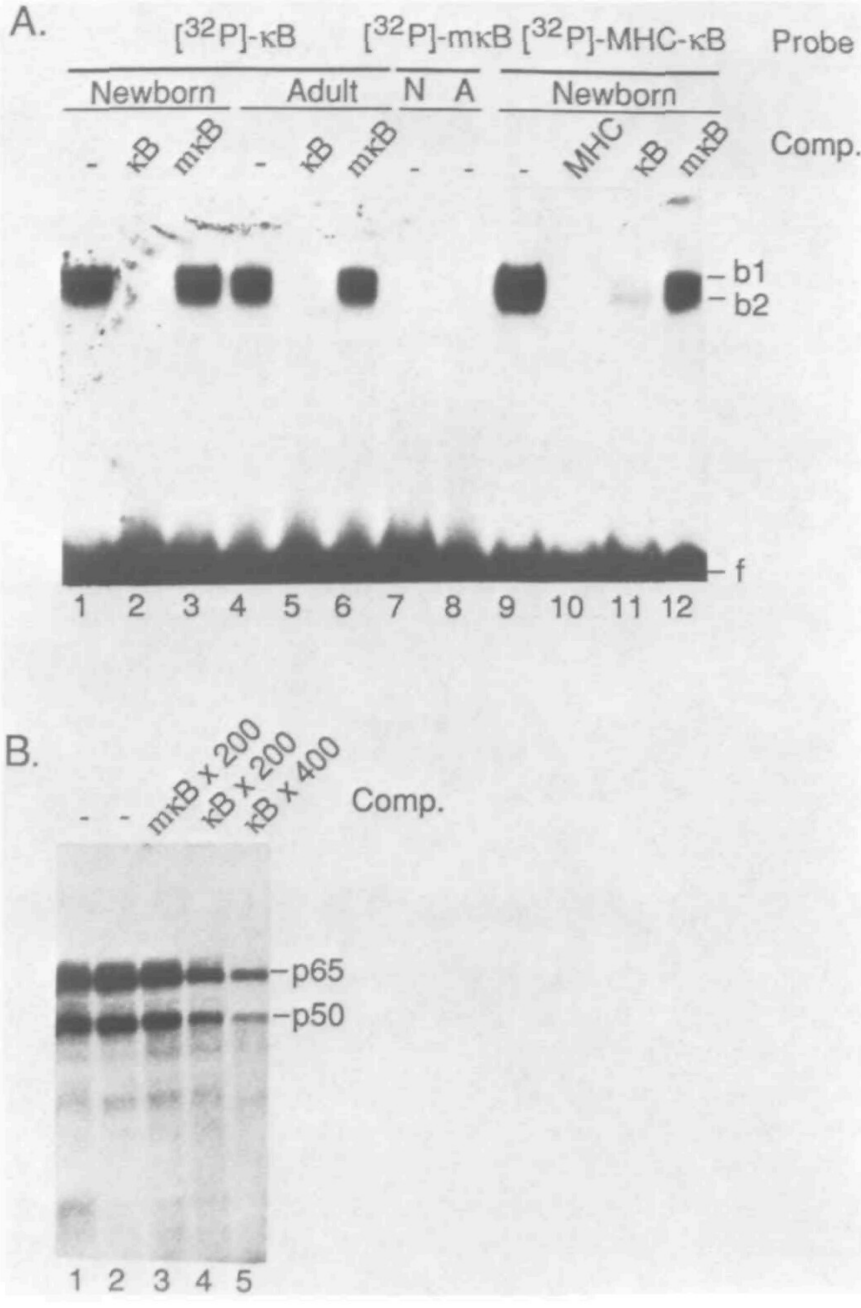

Fig. 1. NF- $x B$ binding activity in nuclear extracts of thymus of newborn and adult mice. (A) EMSA was done using three labeled digonucleotides. $x \mathrm{~B}, \mathrm{~m}_{x} \mathrm{~B}$, and $\mathrm{MHC} \cdot x \mathrm{~B}$ (see Table 1 for oligonucleotide sequences) $\mathrm{A}$ 200 -fold molar excess of each unlabeled oliognucleotıde was used in the competition experiments. N, newborn; $A$, adult mouse. The arrows b1 and b2 indicate the moblity of NF-xB-DNA complexes. (B) Detection of NF. $x$ B proten subunits by UV cross linking to $\left[^{32} \mathrm{P}\right] x \mathrm{~B}$ ofigonucleotide and SDS - PAGE. DNA-binding reactions were performed with total protein extract of thymuses of newborn mice without competitors (lanes 1 and 2) or in the presence of 200-fold molar excess of $\mathrm{m} x \mathrm{~B}$ oligonucleothde (lane 3), or 200 - or 400 -fold excess of $x \mathrm{~B}$ ofigonucleotide (lanes 4 and 5). $x \mathrm{~B}$ oligonucleotide was crosslinked after DNA-binding reaction with sequence-specific proteins using UV treatment. Then labeled proteins were analyzed by $0.1 \%$ SDS - $10 \%$ polyacrylamide get electrophoresis with protein markers. The main protein suburits of NF- $\mathrm{xB}$ were destgnated as $p 50$ and $p 65$.

precursor pool was evident. A similar inverse correlation was seen between nuclear and cytoplasmic NF-xB in samples obtained from newborn and adult thymocytes (Fig. 3, lanes 14 and 19).

\section{CREB binding activity during thymus ontogeny}

CREB activity in fetal and adult mouse thymocytes was determined using labeled CRE oligonucleotide (which contains a binding site for the CREB transcription factor) (Fig. 4). Competition expenments with different unlabeled oligonucleotides confirmed the specificity of CREB binding activity (Fig. 4, panel

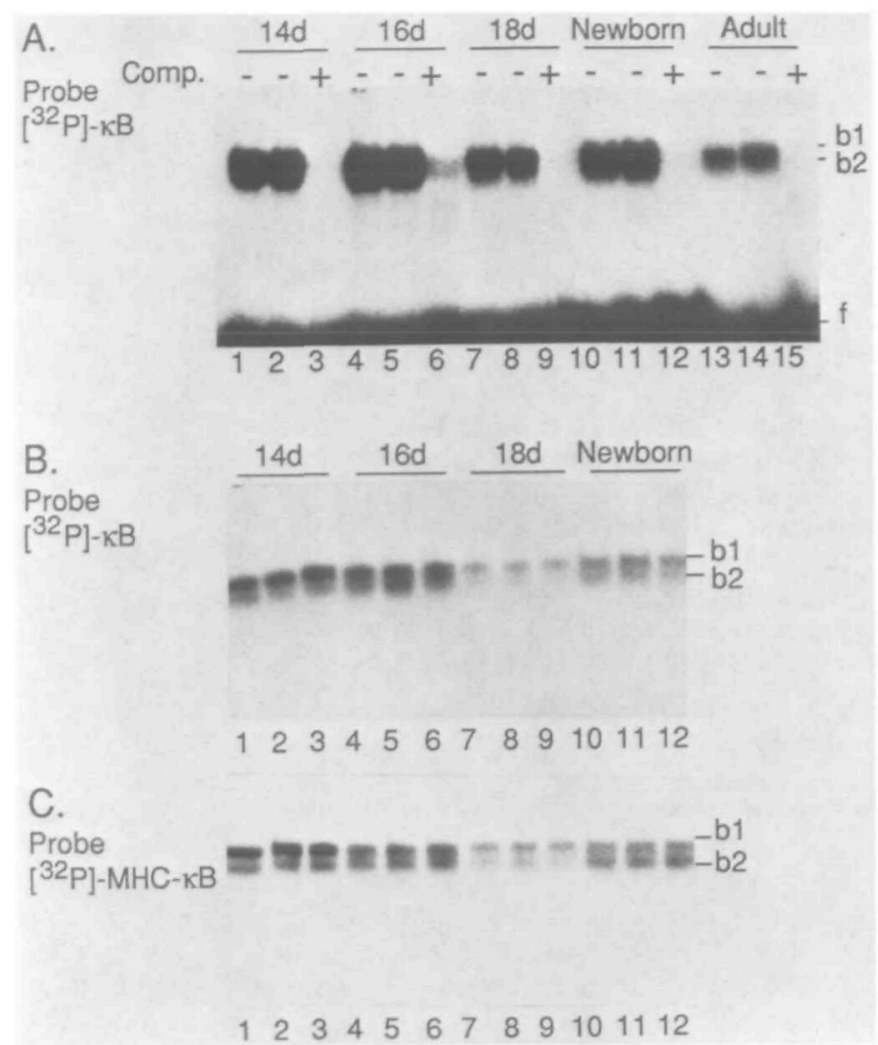

Fig. 2. NF. $x$ B binding activity in nuclear extracts of mouse thymus from different stages of development Stages of development (14 days, 16 days, 18 days of embryonic development, and newborn and adult) are shown on the top. EMSA was done using two labeled probes. [ $\left.{ }^{32} \mathrm{P}\right] \times \mathrm{B}$ olıgonucleotide (panels $\mathrm{A}$ and $\mathrm{B}$ ) and $\left.\mathrm{I}^{32} \mathrm{P}\right] \mathrm{MHC}-x \mathrm{~B}$ digonucleotides (panel C) A 200-fodd molar excess of urdabeled $x \mathrm{~B}$ oligonucteotide were used as competitor (Comp + ). The arrows b1 and b2 indicate the mobility of NF. $x B$-DNA complexes, the arrow $f$ indicates the free DNA probe

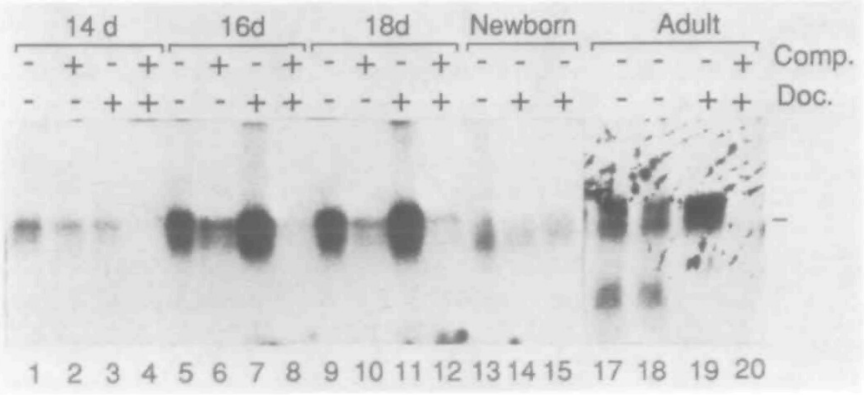

Fig. 3. Presence and specificity of the precursor of NF*xB transcription factor in the cytoplasmic extracts of mouse thymus from different stages of devetopment. EMSA was done using labeted $x B$ oligoructeotide probe. Cytosolic extracts were treated with $0.6 \%$ sodium deoxycholate (Doc. + ) prior to DNA binding reactions or not treated (Doc. -) and then analyzed on $4 \%$ non-denaturate polyacrylamide gel. The presence ol compettor. 200 -fold molar excess of unlabeled $x$ B-oligonucleotide is designated as Comp. +

A). Interestingly, an excess of the AP-1-bınding oligonucleotide (which differs from the CREB sequence by only one base) did not inhibut CREB binding activity (Fig. 4A, lanes 5 and 6). The 


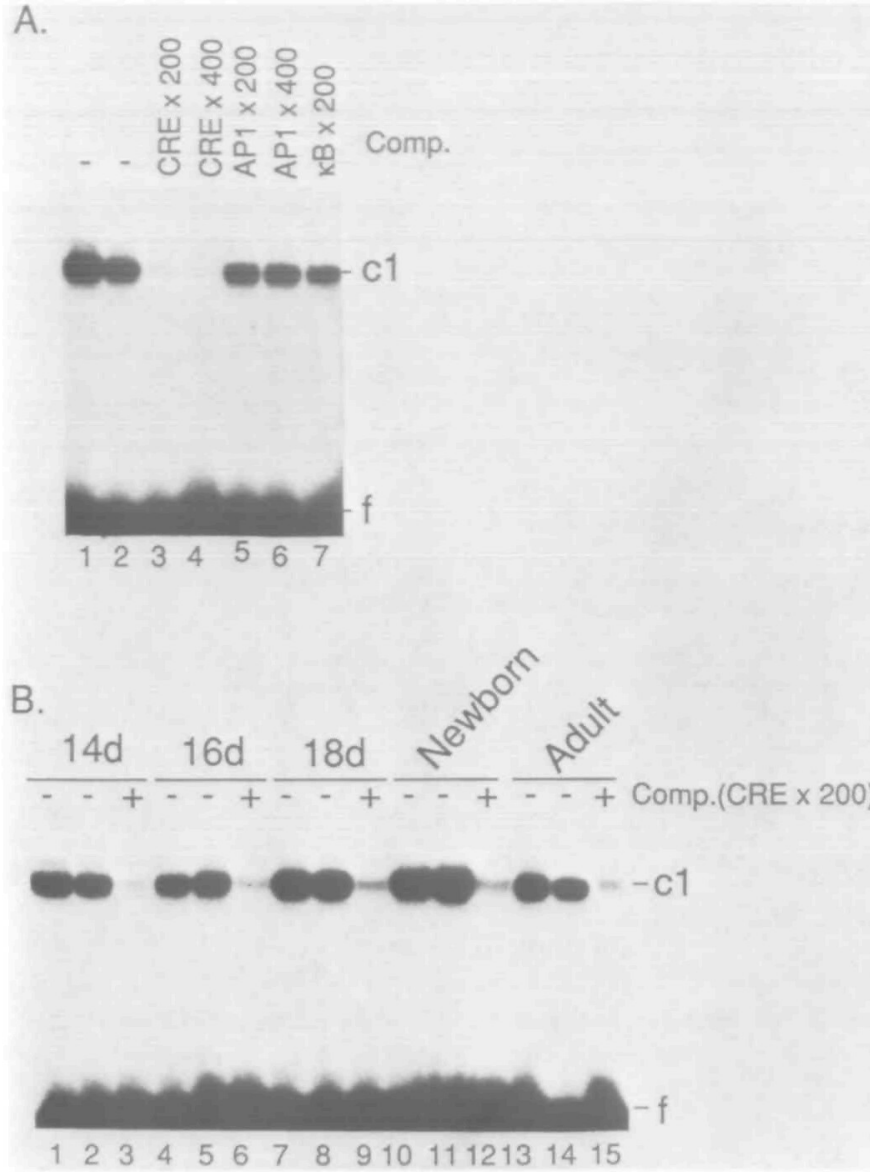

Fig. 4. CREB banding activity in nuclear extracts of thymus from different stages of development (A). Specificity of CREB binding activity EMSA was done using labeled CRE oligonucleotide without competitions (lanes 1 and 2) or in the presence of 200- or 400-fold excess of unlabeted CRE oligonucleotide (lanes 3 and 4 respectively), or 200- or 400-fold excess of unlabeled AP1-bunding oligonucleotide (lanes 5 and 6), or 200-fold excess of $x$ B oligonucleotide (lane 7) The arrow $c 1$ indicates the moblity of the CREB - DNA complex, $f$ Indicates the free oligonucleotide probe. (B). CREB activity during thymus development. The presence of 200-fold molar excess of unlabeled CRE oligonucleotide as competitor is designated Comp +

level of CREB binding activity increased slightly during fetal thymus development, peaking at birth and then decreased to the adult level ( $\mathrm{Fig} 4 \mathrm{~B}$ ). The main band of retardation was designated $\mathrm{c} 1$ and longer exposure revealed some additional minor bands of retardation (not shown).

\section{NF-IL-2A and NF-AT1 transcription factors during thymus ontogeny}

The presence and specificity of NF-IL-2A binding activity in mouse thymocytes was determined by EMSA with a labeled IL-2A oligonucleotide containing the cognale sequence for the NF-IL-2A transcription factor (Table 1). Specificty analyses using competitor digonucleotides are shown in Fig. 5(A and B). Three distinct DNA - protein complexes were observed. Bands a1 and a2 were specific, while a3 was only partly inhibited by unlabeled IL.2A oligonucleotide (Fig. 5A, lanes 3 and 4). Shorter exposures (6 h) of the same autoradiogram (panel $B$ ) revealed that unlabeled $x B$

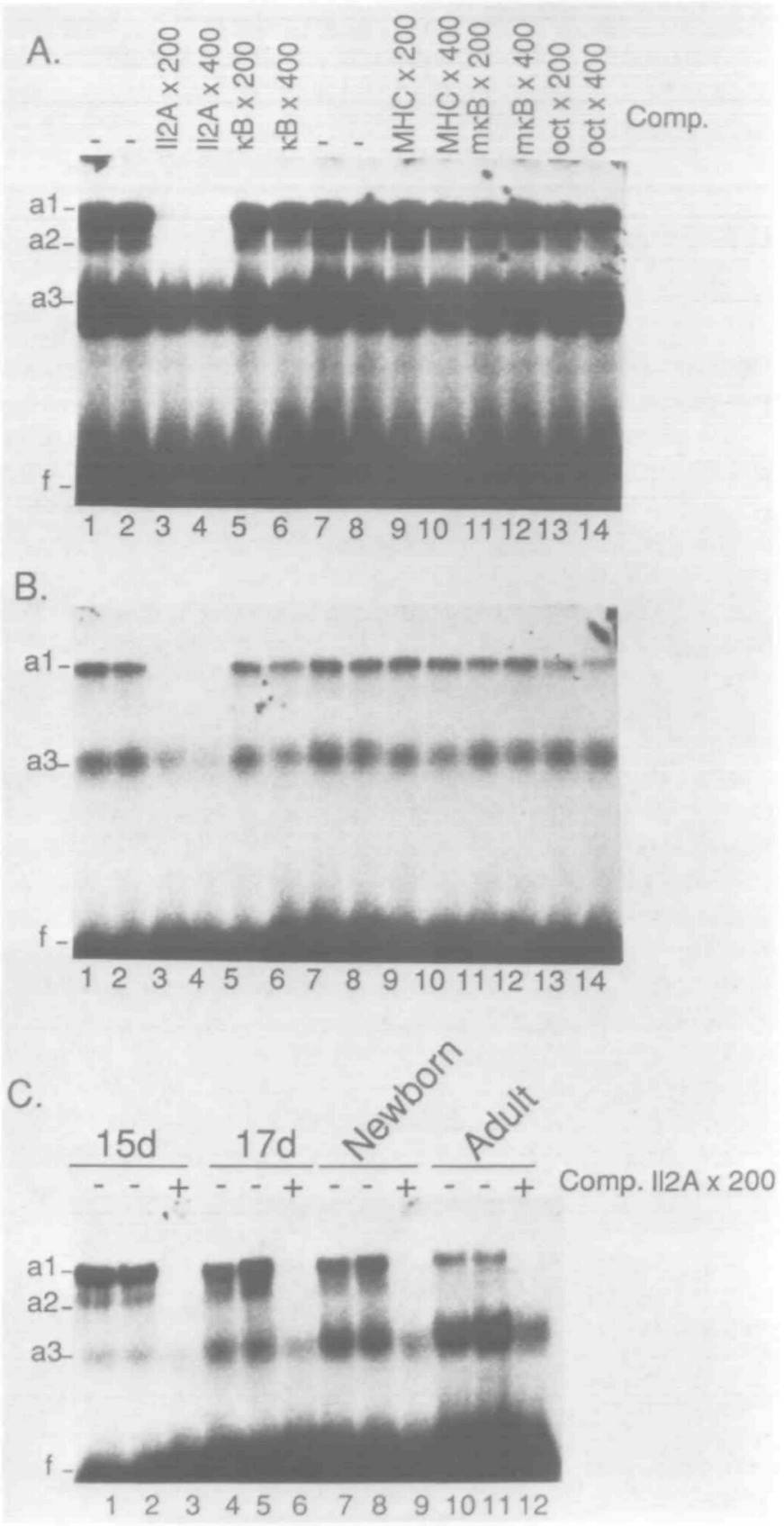

Fig. 5. NF-IL-2A binding activity in nudear extracts of mouse thymus from different stages of development. (A) and (B) Specificity of NF.IL.2A binding activity. Panet $(B)$ is the same as panet $(A)$ but after a short-tıme exposure of the autoradiogram (6 h). EMSA was done using labeled IL-2A oligonucleotide probe without any competitor (lanes 1,2,7 and 8) or in the presence of 200 - or 400 -fold molar excess of different oligonucleotides (see Table 1 for oligonucleotide sequences). The arrows at $\mathrm{a} 1, \mathrm{a} 2$, and $\mathrm{a} 3$ indicate mobilities of different NF-IL-2A-DNA complexes, $f$ indicates the free ofgonucteotide probe. (C) NF.IL-2A activity during thymus development. The presence of 200 -fodd molar excess of unlabeled IL-2A oligonucleotide as competitor is designated Comp. + .

oligonucleotide, MHC $x$ B-oligonucleotıde, but not $\mathrm{M} x \mathrm{~B}$ oligonucleotide, partly reduced the intensity of the a3 band. In addition, a 400 -fold molar excess of $x \mathrm{~B}$ oligonucleotide partly inhibited labeling of band a1 (Fig. 5B). 
Similarity between human NAF-IL-2A factor and the ubiquitous Oct1 protein has recently been established $(22,38)$. We used an digonucleotide with a canonical motif as a competitor for NFIL-2A bınding activity in EMSA experiments (Fig. 5A and B, lanes 13 and 14). We observed only partial inhibition of mouse NFIL-2A binding activity (bands a1 and a2, but not for band a3) by excess unlabeled octamer oligoncleotide. This partial inhtbition was seen more clearly after shorter exposure of autoradiograms (panel B). It is possible that bands a1 and a2 represent Oct1 and Oct2 factors whereas band a3 represents a complex between Oct1 and a $40 \mathrm{kDa}$ Oct1-associated protein as recently suggested by Ullman et al. (39).

The ontogeny of NF.IL-2A binding activity in the thymus is shown in Fig. 5(C). The intensity of bands a1 and a2 were high initially but then decreased in the adult thymus. Band a2 seems to be absent in the adult. In contrast, the intensity of band a3 dramatically increased during development

A complex picture emerged when the ontogeny of NF-AT1 factor binding activity was analyzed. Using a labeled oligonucleotide with the canonical NF-AT1 binding site from the human IL-2 gene enhancer (17) we detected two DNA - protein retarded complexes (Fıg. 6). From competition experiments with homologous and mutated oligonucleotides, only the lower of these two bands was specific (Fig. 6, lanes 10-13). When we used as competitor an olıgonucleotıde with the equivalent mouse NF-AT1 (msAT) binding site, which differs from the human by only two nucleotides (40) (see Table 1), we saw no inhibition of bınding to the human NF-AT oligonucleotide (Fig. 5A, lane 13). Furthermore, when the mouse probe was used as the labeled oligonucleotide, several bands were observed only one of which was specific (msNF-AT1). The upper, non-specific band (revealed using human NF-AT1 probe) (lanes $10-13$ ) was also recognized using the mouse probe (lanes 14 and 15). From these experiments, it seemed that the human and mouse probes were detecting specifically two different proteins which we have designated hNF-AT1 and msNF-AT1 respectively.

The ontogeny of hNF-AT1 and msNF-AT1 appeared to be different. Thus, significant levels of hNF-AT1 activity were observed in the fetal thymus from day 14 (Fig. 7, lanes 16-18; Fig. 6A, lanes $1-9$ ) and this activity contınued to increase with age. However, we were unable to detect specific msNF-AT1 (the lower band) at day 14 , but by day 16 this became barely detectable, and thereafter increased in concentration to that seen in the adult thymus (Fig. 6, Panel B).

\section{Fetal liver transcription factor}

Having established the pattern of expression of several ubiquitous transcription factors in the 14 day fetal thymus, we wanted to compare the pattern seen in thymocytes with a tissue known to be a rich source of precursor cells, i.e. the fetal liver. Results of these experiments are shown in Fig. 7. Fetal liver cell suspensions were enriched for hemopoietic cells by centrifugation over a Hypaque-Ficoll gradient prior to nuclear protein purification. No difference in NF-IL-2A or hNF-AT1 binding activity between fetal liver and thymocytes was observed. CREB activity was significantly increased in the thymus compared with fetal liver extracts. However, the most dramatic difference was seen with $\mathrm{NF}-\boldsymbol{x} \mathrm{B}$, which was practically absent in fetal liver cells but present at a high level in thymocytes.

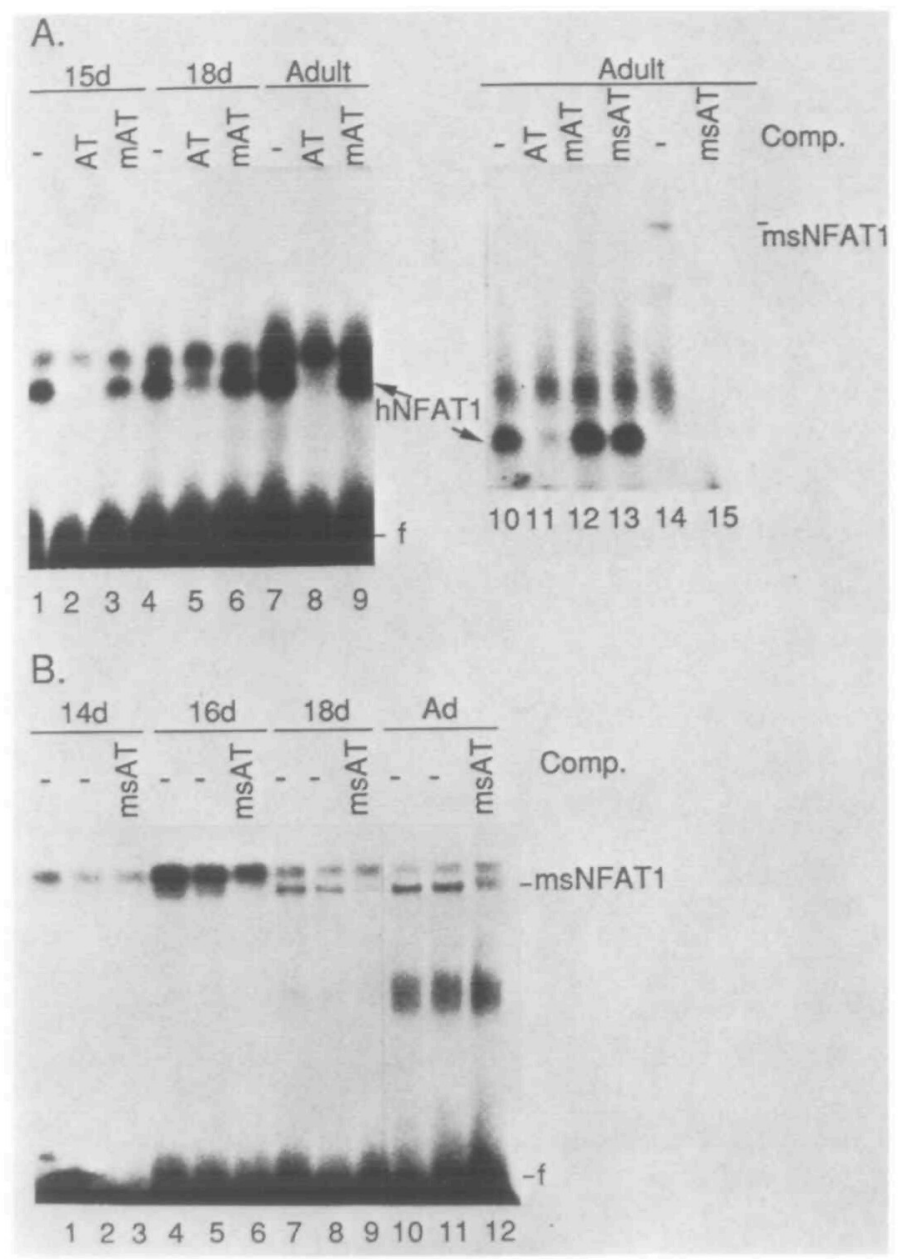

Flg. 6. NF-AT1 binding activity in nuclear extracts of mouse thymus from different stages of development. EMSA was done using two labeled probes: human NF-AT1 binding oligonucleotide (panet A, lanes 1 - 13) or mouse NF.AT1 binding odigonucleotide (panel A, lanes 14 and 15, and panel $B$ ). A 200 -fold molar excess of three different oligonucleotides, I.e. human NF-AT1 binding olıgonucleotıde (AT), a mutated variant of this oligonucleotide (mAT), and mouse NF-AT1 binding oligonucleotide (mSAT), was used as competitor. The arrow hNF.AT 1 indicates the position of the NF-AT1 - DNA complex revealed by the human probe and msNFAT1 indicates the moblity of the DNA - protenn complex revealed by the mouse probe.

\section{Dlscussion}

In this report, EMSA experiments have been carried out using nuclear and cytoplasmic extracts of fetal mouse thymocytes in order to determine qualitative and quantitative aspects of transcription factor expression. The transcription factors studied included NF- $x$ B, CREB, NF-IL-2A, NF-AT1, NF-1, and AP-1, and these were chosen because of their known critical involvement in the regulation of genes active in mature, immunocompetent $T$ lymphocytes.

At day 10.5 of development, the mouse thymus is a cluster of epithelial cells which becomes colonized by blood-borne, fetal Iver-derived hemopoietic cells. Over the next few days, migration of fetal liver cells continues and, by day 14 , the thymus contains $1-2 \times 10^{4}$ hemopoietıc cells and an equal number of epithelial 

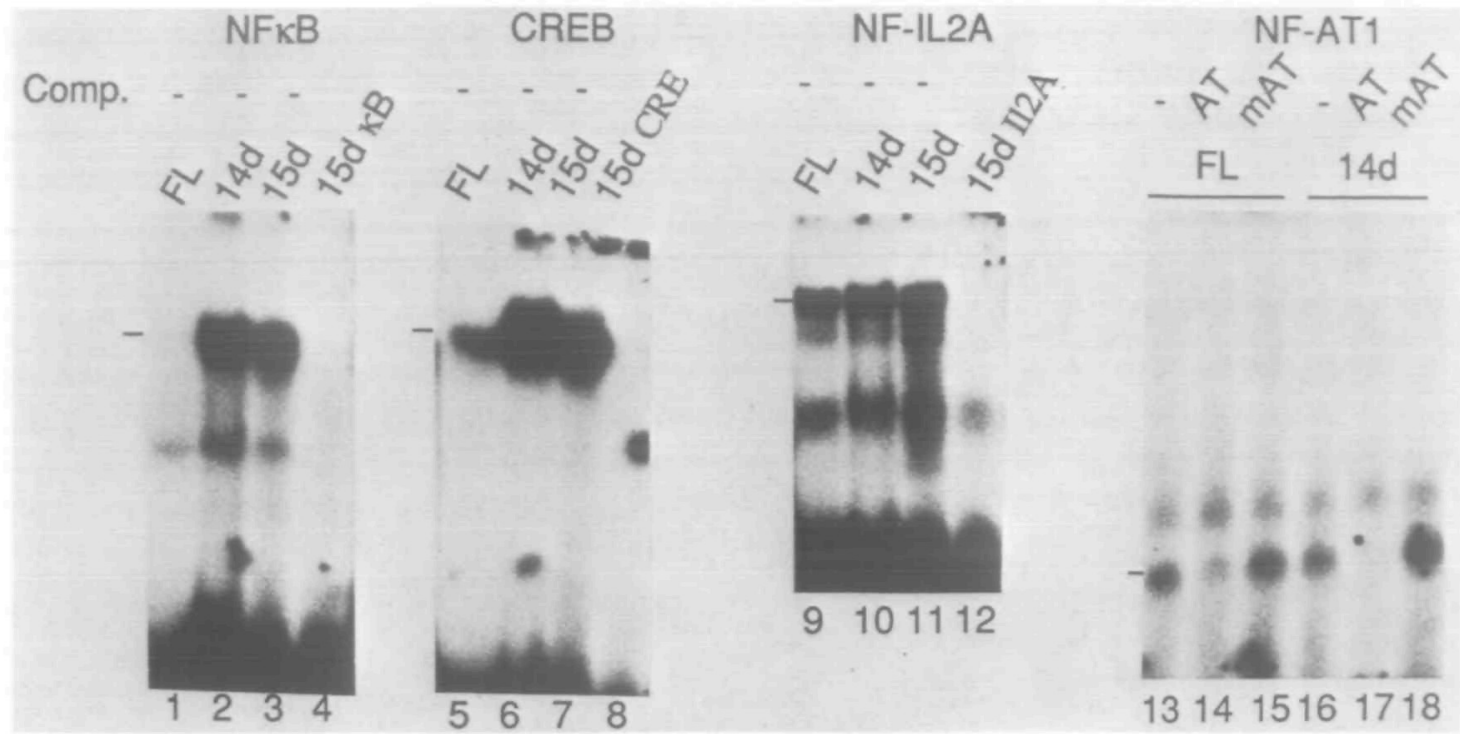

Fig. 7. Transcription factor binding activity in fetal liver and thymus ( 14 and 15 days of gestation). EMSA was done using labeled probe for the detection of NF-xB, CREB, NF-IL-2A, and NF-AT1 binding activities. DNA binding reactions were performed without competitor (Comp -) or in the presence of 200 -fold molar excess of unlabeled $x$ B oligonucleotide (lane 4), CRE oligonucleotide (lane 8), IL-2A oligonucleotide (lane 2), human NF-AT1 binding oligonucleotıde (AT, lanes 14 and 17), or a mutated varıant of this oligonucleotide (mAT; lanes 15 and 18). The dashed lines Indicate the postions of specific DNA - proten complexes.

cells. Very little is known about the interaction(s) between epithelial cells and hemopoietic precursors at this critical time of thymocyte development. Most hemopoietic cells in the 14 day thymus do not express cell surface TCRs.

However, beginning at day 14, surface expression of gamma/delta TCR can be detected on about $3 \%$ of cells and a truncated form of TCR- $\beta$ chain transcripts can be identified. In addition, $-50 \%$ of cells express on their surface IL-2R $\alpha$ chains although IL-2 is not thought to play a role in the growth of fetal thymocytes at this time (41). By day 16 of development, cells expressing both CD4 and CD8, double positive thymocytes appear, followed soon after by single positive $\mathrm{CD}^{+}{ }^{+}$and $\mathrm{CD} 8^{+}$ cells. Coincident with the appearance of double positive cells, surface expression of the TCR- $\alpha / \beta$ can be detected (for review, see ref. 23). During this time, the thymus is growing exponentually, reaching $\sim 5 \times 10^{6}$ cells at day 20 (birth) and $\sim 2 \times 10^{8}$ cells in the 4 week adult organ. It can be shown using organ cultures that this differentiation process is independent of external Influences; the 14 day fetal thymus contains all the cells and factors necessary to carry out this complex differentiation process (26).

Expression of functional TCR- $\alpha / \beta$ in association with the co-receptor molecules CD4 and CD8 are known to be crucial for cell signalling processes involved in TCR- $\alpha / \beta$ receptor selection. Although at the phenotypic level much is known about the ontogeny of thymocyte subpopulations and of TCR receptor gene rearrangements, the mechanisms by which transcription factors regulate the expression of these important events are largely unknown. The experiments reported herein were designed to provide information regarding the baseline expression of transcription factors during thymus ontogeny.

Starting with NF- $x$ B, EMSA experiments revealed that there was a distinct pattern of expression dunng thymus development.
Whereas fetal liver cells from day 14 embryos contained no detectable NF- $x$ B binding, thymocyte nucles at this time contained abundant activity. As pointed out above, 14 day fetal thymocytes are heterogeneous, as are the fetal liver cells isolated herein. Indeed, the frequency among Ficoll-separated fetal liver cells capable of recolonizing the fetal thymus is of the order of $1 / 10^{4}$ (42). In the experiments reported herein, no attempt has been made to purify subpopulations of fetal liver cells or thymocytes. Nevertheless, distinct differences were noted between fetal liver and thymocytes from 14 day embryos, and we therefore consider the increase in NF. $x$ B expression between fetal liver and thymus to be significant especially since other transcription factors remained unchanged.

By the criteria of subunit composition and binding specificity, the binding activity to the NF- $x B$ specific oligonucleotide of mouse thymus extracts corresponds to NF-x B which is composed of distinct DNA binding (p50) and transactivation (p65) subunits $(35,43)$.

During thymus development, an inverse correlation between nuclear and cytoplasmic concentrations of NF- $x$ B was noted. It is well known that NF- $x B$ resides in the cytoplasm in an inactive form, complexed to an inhibitor $\left.\right|_{x} \mathrm{~B}$, and that cellular activation results in the dissociation of $1 x B$ from NF- $x B$ with consequent releases of active NF- $x B(36)$. The dissociaton of $\mid x B$ from NF$x B$ can be regulated in many ways including free radicals (44) and phosphorylation of $1 \times B$ by protein kinase (45). It is also known that the $p 50$ subunit of NF- $x B$ is initially synthesized as a precursor of $105 \mathrm{kDa}$ which requires processing to generate active binding protein $p 50(33,46)$. Thus the rate of synthesis of the $p 50$ subunit will also regulate the effective concentration of $\mathrm{NF} \cdot x \mathrm{~B}$.

The $\mathrm{p} 50$ and $\mathrm{p} 65$ subunits of NF- $x \mathrm{~B}$ transcription factor have been recently cloned and shown to belong to the Rel-related transcription factor family $(33,46-48)$. Using EMSA and UV 
crosslinking with SDS-PAGE, we have shown that nuclear extracts of developing thymocytes contained both the heterodimeric (p65 - p50) and homodimeric ( $p 50-p 50) N F-x B$ complexes. The ratio of these complexes changed during thymus ontogeny with the highest p65 - p50 activity being found in the day 14 fetal thymus. As the $p 65-p 50$ NF- $x$ B complex is a much more effective transactivator than the p50 - p50 complex (49) these changes in the ratio of p65-p50 to p50-p50 probably reflect changes in target gene expression mediated by NF.x $\mathrm{B}$ during thymus ontogeny. Presumably, the increase in NF.xB expression by fetal liver cells entering the thymus must be regulated by a TCR-independent mechanism and is thus different from that seen following TCR-mediated stımulation of mature T lymphocytes. Because NF- $x B$ is known to be involved in the control of IL-2R (50) and IL-2 (51) gene expression in mature T cells, it is possible that alterations in subunit composition combined with the high nuclear concentrations of NF- $x B$ in the day 14 fetal thymus may be involved in regulatıng IL-2R expression by fetal mouse thymocytes. Thus, NF- $x B$ may play a crucial role in early fetal thymus development.

For NF-AT1, the pattern of expression during thymus development was also complex. Using oligonucleotides corresponding to either the human IL-2 gene enhancer or the equivalent mouse sequence, EMSA experıments suggested that the mouse thymus contains at least two different NF-AT1 proteins which we have designated hNF-AT1 and msNF-AT1. These two proteins had different patterns of expression during ontogeny. Thus, whereas hNF-AT1 appeared to be an ubiquitous factor expressed at a constant level throughout ontogeny (a pattern also seen with CREB and NF-1) msNF-At1 appeared to be developmentally regulated being first detectable on day 16 of thymus development. The tuming of msNF-AT1 expression is significant since by polymerase chain reaction (PCR) analysıs, IL-2 transcription could be initially detected only at day 16 of thymus development (52). This result differs from a previous report using in situ hybridization in which two waves of IL-2 transcription at days 14 and 16 could be detected (53). Thus our EMSA experiments suggest that msNF-AT1 may be involved in IL-2 gene expression during thymus development, beginning at day 16. It should be pointed out that the human NF. AT1-binding oligonucleotides used in this study contained an Ets binding site whereas in the mouse digonucleotide this sequence was truncated and modified (Table I). The presence of this Ets cognate sequence may account for the differences observed in EMSA using either mouse or human oligonucleotides.

NF-IL-2A was present at a high level throughout thymus development. Recently, it has been shown that NF-IL-2 and the $90 \mathrm{kDa}$ Oct1 factor are proteins with related sequence specificity (38). A possible interpretation of multiple bands of retardation formed by thymic nuclear extracts with labeled IL-2A oligonucleotide in EMSA is that band a1 and a2 represent Oct1 and Oct2 factors whilst band a3 is a heteromeric complex between NF-IL-2A and Oct1-associated protein (39). The dramatic increase in the intensity of band a3 during thymus development suggests that this type of interaction between different transcription factor subunits increases during thymus development.

The thymus is the primary organ where $T$ lymphocytes are generated. Studies to date have concentrated on the phenotypic and lunctional description of events that take place in the developing thymus. However, we remain largely ignorant as to the molecular mechanısms governing thymocyte growth and survival, particularly durıng the early stages of fetal thymus development. Ultumately, the complex series of events that guides the differentiation of precursor $T$ cells to functional mature $T$ lymphocytes must be regulated at the gene transcriptional level The recent cloning of genes encoding transcription factor proterns means that attempts can now be made, using transgenic mouse technology, to manipulate the avalability of such transcription factors in developing thymocytes. By this means, the roles of transcription factors in controlling thymocyte differentiation can be investigated.

\section{Acknowledgements}

We would like to thank A Fisher, C Benoist, and D. Mathis for critical reading of the manuscript. A. Staub for oligonucleotıde synthesis, and J.M. Lafontaine and C Werle for preparatıon of illustratıons This work was supported by institutional grants from INSERM, CNRS, and ARC. V.I was supported by CIES.

$\begin{array}{ll}\text { Abbreviatlons } & \\ \text { CREB } & \text { c-AMP-response-element binding protein } \\ \text { EDTA } & \text { ethylendiamıne tetra-acetic acid } \\ \text { EMSA } & \text { dectrophoretic moblity-shitt assay } \\ \text { DOC } & \text { granulocyte macrophage colony stimulating factor } \\ \text { GM-CSF } & \text { human immunodeficiency virus } \\ \text { HIV } & \text { IL-2 receptor } \alpha \text { chain } \\ \text { IL-2R } \alpha & \text { nuclear factor } x \text { B } \\ \text { NF- } x \text { B } & \text { nuclear factor of activated T cells } 1 \\ \text { NF-AT1 } & \text { phenylmethylsufonyl fluoride } \\ \text { PMSF } & \text { polymerase chain reaction } \\ \text { PCA } & \text { sodium dodecylsulfate } \\ \text { SDS } & \text { T cell receptor } \beta \text { chain } \\ \text { TCR- } \beta & \text { tumor necrosis factor } \alpha \\ \text { TNF- } \alpha & \end{array}$

\section{References}

1 Mitchell, P. J. and Tjian, R. 1989. Transcriptıonal regulatıon in mammalian cells by sequences-specific DNA binding proteins Science 245:371.

2 Jones, N. 1990. Structure and function of transcription factors. Sem. Cancer Bios. 15

3 Weintraub, H., Davs, R., Tapscott, S, Thayer, M., Krause, M , Benezra, R., Blackwell, T. K, Turner, D., Rupp, R., Hollenberg. S Zhuang, Y., and Lassar, A. 1991. The myoD gene family: the nodal point during specification of the muscle cell uneage. Scienco 251.761.

4 Tsai, S.-F., Strauss, E., and Orkın, S. H. 1991 Functional analysis and in vvo footprintıng implıcate the erythroid transcription factor GATA-1 as a positive regulator of its own promoter. Genes Dev 5919

5 Xanthopoulos, K, Prezioso, V. P., Chen, W. S., Saldek, F. M., Cortese R., and Darnell, J. E 1991. The different tissue transcnption patterns of genes for NHF1, C-EBP, HNF-3 and HNF-4, protein factors that govern Iver-specific transcription. Proc. Natl Acad. Sc. USA 88:3807.

6 Waterman, M L., Fischer, W. H., and Jones, K A. 1991 A thymus. specific member of the HMG protein family regulates the human $T$ cell receptor $C_{a}$ enhancer. Genes Dev. 5.656.

7 Travs, A., Amsterdam, A., Belanger. C., and Grosschedet, R. 1991. LEF1, a gene encoding a lymphoid-specific with protein, an HMG domain, regulates T-cell receptor $\alpha$ enhancer function. Gene Dev 5:880.

8 Ho, I.C., Vorhees, P., Marin, N, Oakdey, B. K., Tsal, S.-F., Orkin, S. 
H., and Leiden, J. M. 1991 Human GATA-3 a lineagerestricted transcription factor that regulates the expression of the T-cell receptor $\alpha$ gene EMBO J. 10:1187.

9 Marine, J. and Winoto. A 1991 The human enhancer-bindıng protein Gata3 binds to several T-cell receptor regulator elements Proc Natl Acad. Sci. USA 88:7284.

10 Lenardo, M. J. and Baltumore, D. $1989 \mathrm{NF} \cdot \boldsymbol{k B}$ : a pletotropic mediator of inducible and tissue-specific gene controf. Cell 58:227.

11 Baeuerle. P. A 1991. The inducible transcription activator NF-xB: regulation by distinct protein subunits Biochim. Biophys. Acta 1072:63

12 Gonzales, G. A., Yamamoto, K. K., Frscher, W. H., Karr, D., Manzet, P., Biggs, W., Vale. W. W., and Montming, M. M. 1989 A cluster of phosphorylation sites on the cyclic AMP-regulated nuclear factor CREB predicted by its sequence. Nature 337749

13 Anderson, S. J , Miyake, S., and Loh, D. Y. 1989 Transcription from murine T-cell receptor $V_{\beta}$ promoter depends on a conserved decamer motif similar to the cyclic AMP response element. Mol. Cell Biol. 9.4835.

14 Takeda, J., Cheng, A., Mauxuon, F., Nelson, C. A., Newberry, R. D. Sha, W. C., Sen, R, and Loh, D. Y. 1990. Functional analysis of the murine T-cell receptor $\beta$ enhancer and characteristics of its DNA binding proteins MOl Cell Biol. 10:5027

15 Ho, I-C. Yang. L -H, Morle, G., and Leiden, J M. 1989. A T-cenlspecific transcriptional enhancer element $3^{\prime}$ of $C_{\alpha}$ in the human $T$ cell receptor $\alpha$-locus. Proc Natl Acad. SCI USA 86:6714

16 Lake, R. A., Wotton, D., and Owen, M. J. 1990. A 3'transcriptional enhancer regulates tissue-specific expresston of the human $\mathrm{CD} 2$ gene EMBO J. 9:3129.

17 Emmet, E. A., Verweij, C. L., Durand, D. B. Higgıns, K. M., Lacy, E., and Crabtree, G R. 1989 Cyclosporin A specifically inhibits function of nuclear protens involved in T-cell activation. Science 246. 1617

18 Flanagan, W. M . Corthesy, B , Bram, R. J , and Crabtree, R G. 1991 Nuclear association of a T-cell transcription factor blocked by FK-506 and cyclosporin A. Nature 352.803 .

19 Fraser, J. D., Irving, B. A., Crabtree, G R., and Weiss, A. 1991 Regulation of interleukin-2 gene enhancer activity by $T$-cell accessory molecule CD28. Science 251:313.

20 Randak, C, Brabletz, T., Hergenrother, M., Sobotta, I, and Serfling, E 1990 Cyclosporin A suppresses the expression of the interleukın 2 gene by inhibiting the binding of lymphocyte-specrfic factors to the IL-2 enhancer. EMBO J. 92529.

21 Leiden, J. M. 1992. Transcriptional regulation during T-cell development the $\alpha \mathrm{TCR}$ gene as a molecular model Immunology Today $13 \cdot 22$

22 Ullman, K. S., Northrop, J. P., Verweij, C L., and Crabtree, G. R. 1990. Transmission of signals from $T$ lymphocyte antigen receptor to the genes responsible for cell prollferation and immune function: the missing link. Annu. Rev Immunot 8.421.

23 Fowkes, B. J., and Pardol, D. M. 1989 . Molecular and cellular events of T-cell development. Adv Immunol. 44.207.

24 Ceredig, Rh., Dialynas, D. P., Fitch, F W., and MacDonald, H. R. 1983. Precursors of T-cell growth factor producing cells in the thymus. Ontogeny, frequency and quantitative recovery in a subpopulation of phenotypically mature thymocyies defined by monoctonal antibody GK-1.5. J. Exp. Med. 158.1654.

25 Maniatis. T., Fritsch, E F , and Sambrook, J. 1982. Molecular Cloning A Laboratory Manual. Cold Spring Harbor Laboratory, Cold Spring Harbor, NY

26 Ceredig, Rh. 1988. Differentiation potential of 14-day fetal mouse thymocytes in organ culture: Analysis of CD4/CD8 defined single positive and double negative cells. J. Immunol. 141.355.

27 Dignam, J. D., Lebovitz, R. M., and Roeder, R. G. 1983 Accurate transcription initiation by RNA polymerase II in a sofuble extract from isolated mammatian nuclei. Nucleic Acids Res. 11:1475.

28 Schreiber, E., Matthias, P., Mueller, M. M., and Schaffner, W. 1989. Rapid detection of octamer binding proteins with 'mini-extracts'. prepared from a small number of cells. Nucleic Acids Res. 17:6419.

29 Bradtord, M. M. 1976. A raptd and sensitive method for the quantitation of microgram quantities of protein using the principle of protein-dye binding. Anal. Biochem. 72.248.
30 Barberıs, A, Supert-Furga, G., and Busslinger, M. 1987. Mutually exclusive Interaction of the CCAAT-binding factor and a displacement proten with overlapping sequences of histone gene promoter. Cell 50:347.

31 Baeuerle, P. A and Battimore, D. 1988. Activation of the DNA.binding activity in an apparently cytoplasmic precursor of the NF-xB transcription factor. Cell 53.211

32 Wu, C., Wilson, S., Walker, B. Dawid, I., Paisley, T., Zmarino, V. and Ueda, H. 1987 Purification and properties of Drosophila heat shock activator protenn. Science 238:1247.

33 Ghosh, S., Giflord, A. M., Rivere, L. R., Tempst, P., Notan, G P. and Baltimore, D. 1990 Clonng of 050 DNA binding subunit of NFxB: homology of ret and dorsal. Cell 62:1019.

34 Urban, M. and Baeuerte, P. A. 1991. The role of the p50 and p65 subunits of NF- $x B$ in the recogntion of cognate sequences. New Biol. 3.279

35 Urban, M., and Baeuerle, P A 1990 The $65 \cdot \mathrm{kD}$ subunit of NF-xB is a receptor for $1 x B$ and moculator of DNA-binding specaficity. Gene Dev 4:1975.

36 Baeuerle, P. A and Baltımore, D. 1988. IxB a specific inhibitor of the NF- $x$ B transcription factor. Science $242 \cdot 540$

37 Haskill, S., Beg, A A., Tompkins, S M., Morris, J. S., Yorochko, A D. Sampson-Johannes, A, Mondal, K., Ralph, P, and Baldwn A S. 1991 Characterization of an immediate-early gene induced in adherent monocytes that encodes IxB like activity. Cell 65.1281.

38 Kamps, M. P., Corcoran, L., LeBowit, J H., and Battimore, D 1990. The promoter of the human interleukin 2 gene contains two octamer. binding sites and is partially activated by the expression of Oct-2 Mol. Cell Biof. 105464.

39 Ullman, K S. Flanagan, W M., Edwards, C. A., and Crabtree, G R. 1991. Activation of early gene expression in T lymphocytes by Oct 1 and an inducible protein, OAp ${ }^{40}$ Science 254:558.

40 Novak, T. J., White, P. M, and Rothenberg, E. V. 1990. Regulatory anatomy of murine Interleukin-2 gene. Nucletc Acıds Res 18.4523.

41 Ceredig, Rh., Lowenthal, J.. Nabholz, M , and MacDonald, H. R. 1985. Expression of interleukın-2 receptor as a differentiation marker on Intrathymic stem cells Nature 314.98 .

42 Fisher. A. Unpublished data

43 Nabel, G. H 1991. Tampering with transcription. Nature 350.658.

44 Schreck, R., Rieber, P., and Baeverle, P. A. 1991. Reactive oxygen intermediates as apparently widely used messengers in the activation of the NF. $x$ B transcription factor and HIV-1 EMBO J. 10.2247

45 Ghosh, S., and Baltımore, D. 1990 Activation $I n$ vitro of NF.xB by phosphorylation of its inhibitor IxB Nature 334.678.

46 Kieran, M., Blank, V, Logeat, F., Vandekerckhove, J., Lottsperch $F$, Bail, O. L., Urban, M. B , Kourilsky, P , Baeuerle, P. A., and Israel, A 1990 The DNA binding subuntt of NF- $x B$ is identical to factor KBF and homologous to the ret oncogene product. Cell 62:1007.

47 Nolan, G. Ghosh, S. Liou, H.C.. Tempst. P., and Baltimore, D. 1991. DNA binding and $l_{x} \mathrm{~B}$ inhibition by the cloned $p 65$ subunt of NF- $x \mathrm{~B}$. a rel-related polypeptide. Cell 64:961.

48 Ruben, S. M . Dillon P. J., Schreck, R, Henkel, T , Chen, C. H., Maher, M., Baeverle, P. A., and Rosen, C. A. 1991. Isolation of a rel-related human cDNA that potentially encodes of the $65-\mathrm{kD}$ subunit of NF. *B. Science $251 \cdot 1490$.

49 Schmid, R. M. Perkuns, N D., Duckett, C. S., Andrews, P. S., and Nabet, G. J. 1991. Cloning of an NF- $x$ B subunit which stimulates HIV transcription in synergy with p65. Nature 352.733

50 Leung, K. and Nabel, G. J. 1988. HTLV-1 transactivator induces interleukn-2 receptor expression through an NF-xB-like factor. Nature 333:776.

51 Hoyos, B., Ballard, D. W., Bohntein, E., Siekewitz, M., and Greene, W C. 1989. Kappa-B specific DNA binding proteins: role in the regulation of human interleukin 2 gene expression. Science 244.457.

52 Dallman, M. J., Montgomery, R. A., Larsen, C. P., Wanders, A., and Wells, A. F. 1991. Cytokine gene expression: analysis using Northern blotting, potymerase chain reaction and in situ hybridization. Immunol. Rev. 119:163.

53 Carding. S. R., Jenkinson, E. J., Kingston, R., Hayday, A. C., Bottomly, K., and Owen, J. J. T. 1989. Developmental control of lymphokine gene expression in fetal thymocytes during T-cell ontogeny. Proc. Natt Acad. Sci. USA 86:3342. 
